\title{
Dampak Program Gerakan Pakan Ikan Mandiri (GERPARI) terhadap Kesejahteraan Petani Ikan di Kelurahan Jembatan Emas Kecamatan Pemayung Kabupaten Batang Hari
}

\author{
Asmaida $^{1}$, Rogayah $^{2}$ \\ 1,2Dosen Program Studi Agribisnis Fakultas Pertanian Universitas Batanghari, \\ Jl. Slamet Riyadi-Broni, Jambi. 36122. Telp. +6274160103 \\ Correspondence email: asmaida.syandri@yahoo.co.id; asmaida@unbari.ac.id
}

\begin{abstract}
GERPARI Program through giving capital and fish feeding machine to fish farming farmers in Kelurahan Mas Bridge subdistrict, Batang Hari District is expected to provide space to farmers to be able to realize the welfare of farmers In accordance with the National Medium Term Development Plan (RPJMN) III. Therefore, it is necessary to see the success rate by evaluating and reviewing the program using welfare indicators according to the Central Statistic Agency (BPS) 2015. This research aims (1) describing the welfare condition of farmers of the GERPARI Program in the village of Bridge Mas Pemayung District of Batang Hari, and (2) analyzing the impact of the GERPARI Program on changes in welfare conditions Farmers. The research method is a survey method using questionnaires. Number of samples as many as 25 farmer program recipients. Descriptive analysis is used to obtain an overview of the welfare level of farmers of the GERPARI Program in Jembatan Emas Village using welfare indicators according to BPS, 2015. The Wilcoxon test was used to analyse the impact of the GERPARI Program on the welfare of farmers in Jembatan Emas village. The results of the study showed (1) the welfare level of farmer households of GERPARI Program before receiving the low-category program of $88 \%$ and medium category as much as $12 \%$, after receiving the welfare level program of farmers Increased to medium category as much as $44 \%$ and with high category as much as $56 \%$. The average level of farmer welfare based on revenue indicators, health, education, levels and consumption patterns, and housing and environment before accepting the program belongs to the low category, while the after receive the program, family consumption standards and patterns, as well as residential and environmental prosperity levels belong to the medium category, while family health and education belong to the high category. (2) The assistance of the program of GERPARI that received fish farming farmers in the Kelurahan Mas Bridge Subdistrict of Batang Hari District gave a significant change to the improvement of household welfare of farmers.
\end{abstract}

Keywords: Impact of GERPARI Program; welfare level; fish farmer

\section{PENDAHULUAN}

Pembangunan perikanan budidaya pada hakekatnya merupakan upaya yang sistematis dan terencana oleh seluruh pemangku kepentingan untuk mengubah suatu kondisi perikanan budidaya menjadi lebih baik, melalui pemanfaatan sumberdaya secara optimal, efektif, efisien dan akuntabel guna mewujudkan kesejahteraan masyarakat secara berkelanjutan sesuai dengan Rencana Pembangunan Jangka Menengah Nasional (RPJMN) III Tahun 2015- 2019, yang telah ditetapkan melalui Perpres No. 2 Tahun 2015.

Komoditas ikan air tawar merupakan komoditas yang mendukung secara langsung program ketahanan pangan dan gizi, yang menghasilkan sumber makanan bergizi bagi sebagian besar penduduk Indonesia. Dari beberapa aspek penggelolaan dan sarana dalam budidaya ikan air tawar salah satu kendala utama yang dihadapi adalah masalah pakan, dimana sebagian besar kebutuhan pakan dipenuhi dari pakan ikan pabrikan yang sangat bergantung kepada bahan baku impor, yaitu tepung ikan. Hal tersebut mengakibatkan sebagian pembudidaya masih menggunakan pakan yang belum terdaftar, kwalitas pakan yang umumnya bermutu rendah dan harga relatif mahal (Dirjen Perikanan Sumberdaya, 2015).

Kementrian Kelautan dan Perikanan berupaya untuk mewujudkan ketahanan pangan dan gizi melalui peningkatan produksi yang mandiri, berdaya saing dan berkelanjutan untuk memenuhi kebutuhan masyarakat. Sehingga kualitas produk perikanan budidaya khususnya komoditas ikan air tawar harus tahan dan kuat dalam menghadapi fluktuasi harga dan nilai tukar rupiah. Salah satu strategi yang ditempuh untuk mewujudkan arah kebijakan pembangunan perikanan budidaya tahun 2015-2019 tersebut adalah meningkatkan kemandirian dalam pengelolaan sumberdaya perikanan air tawar, dengan memperkuat kemandirian kawasan dan pengelolaan sarana produksi. Kemandirian sarana produksi saat ini didorong melalui Gerakan Pakan Ikan Mandiri (GERPARI).Program GERPARI berupaya mengurangi ketergantungan terhadap bahan baku pakan impor dan pakan ikan pabrikan, dengan lebih memanfaatkan bahan baku lokal, yang diharapkan bisa menjadi model bisnis pengembangan pakan ikan di Indonesia (Kementerian Kelautan dan Perikanan, 2015).

Hasil penelitian Asmaida, 2018 menyatakan bantuan yang diterima kelompok tani Usaha Sumber Harapan di Kelurahan Jembatan Emas Kecamatan Pemayung Kabupaten Batang Hari yang diberikan Mentri Kelautan dan Perikanan melalui Program GERPARI berupa kendaraan roda tiga, mesin pakan, Gudang Pakan dan modal kerja pembuatan pakan, sangat memberikan manfaat secara ekonomi bagi petani usaha budidaya ikan, karena program ini mampu meningkatkan pendapatan petani walaupun belum optimal secara keseluruhan. Berdasarkan uraian di atas, memperlihatkan bahwa Program GERPARI melalui pemberian modal dan mesin pakan ikan tersebut telah dapat memberi ruang kepada masyarakat untuk dapat mewujudkan kesejahteraan masyarakat secara berkelanjutan sesuai dengan Rencana Pembangunan Jangka Menengah Nasional (RPJMN) III. Untuk itu, maka perlu dilihat lebih lanjut tingkat keberhasilannya 
dengan melakukan evaluasi dan kajian terhadap program tersebut dengan menggunakan indikator kesejahteraan menurut Badan Pusat Statistik (BPS) 2015. Indikator yang tepat adalah dengan menggunakan analisis terhadap indikator pendapatan, kesehatah, pendidikan, taraf dan pola konsumsi serta perumahan dan lingkungan terhadap perubahan kesejahteraan petani sebagai dampak dari adanya program GERPARI dalam berusaha budidaya ikan di Kelurahaan Jembatan Emas Kabupaten Batang Hari. Data dan informasi yang diperoleh dari evaluasi dan kajian tersebut sangat penting artinya dalam merumuskan kembali alternatifalternatif program yang dapat di ambil untuk meningkatkan kesejahteraan dan memecahkan permasalahan pembudidaya ikan pada masa akan datang. Berdasarkan hal tersebut maka dilakukanlah penelitian dengan judul Dampak Program Gerakan Pakan Ikan Mandiri (GERPARI) Terhadap Kesejahteraan Petani Ikan Di Kelurahan Jembatan Emas Kecamatan Pemayung Kabupaten Batang Hari, dengan tujuan penelitian sebagai berikut : (1) Mendeskripsikan kondisi kesejahteraan petani ikan sebelum dan setelah adanya Program GERPARI dalam berusaha budidaya ikan di Kelurahan Jembatan Emas Kecamatan Pemayung Kabupaten Batang Hari. (2) Menganalisis dampak Program GERPARI terhadap perubahan kondisi kesejahteraan petani ikan di Kelurahan Jembatan Emas Kecamatan Pemayung Kabupaten Batang Hari.

\section{Tinjauan Teori}

Menurut Efendi I, 2004, budidaya perikanan didefinisikan sebagai suatu kegiatan untuk memproduksi biota (organisme) akuatik secara terkontrol dalam rangka untuk mendapatkan keuntungan (profit). Kegiatan budidaya mencakup usaha pemeliharaan untuk mempertahankan kelangsungan hidup (survival), menumbuhkan (growth) dan memperbanyak (reproduction) biota akuatik.

Salah satu kendala utama dalam budidaya ikan adalah masalah pakan. Pakan adalah merupakan segala macam bahan makanan yang tersedia atau sengaja diberikan pada ikan pemeliharaan yang dapat segera dimakan oleh ikan secara langsung. Faktor makanan merupakan peranan yang sangat penting dalam pertumbuhan individu ikan. Untuk merangsang pertumbuhan ikan yang optimal diperlukan jumlah dan mutu makanan yang tersedia dalam keadaan cukup dan sesuai dengan kondisi perairan. Berkaitan dengan pakan, maka dihadapkan pada masalah-masalah, yaitu kuantitaif, kualitatif, kontinuitas, dan keseimbangan zat pakan yang terkandung didalamnya. Tujuan pemberian pakan yang berkualitas adalah untuk memperoleh pertambahan daging ikan yang banyak dalam waktu yang singkat. Selain pakan yang berkulalitas, kecepatan pertumbuhan ikan juga tergantung pada jumlah atau kuantitas pakan pakan yang diberikan, ruang suhu, air dan faktor lainnya. Pakan yang dimanfaatkan oleh ikan pertama digunakan untuk memelihara tubuh dan menggantikan sel-sel tubuh yang rusak, setelah itu baru kelebihan pakan yang tersisa digunakan untuk pertumbuhan (Sunarso dan M. Crishtianto, 2000).
Sebagian besar kebutuhan pakan dipenuhi dari pakan ikan pabrikan. Kebutuhan bahan baku pakan nasional (pabrikan) sebagian besar masih berasal dari bahan baku impor, sehingga berdampak pada tingginya harga pakan. Dalam upaya mendorong penurunan harga pakan, serta mengingat kebutuhan pakan ikan untuk memenuhi target produksi tahun 2017 yang mencapai 8,72 juta ton. Pakan ikan menjadi komponen produksi utama yang menentukan keberhasilan produksi perikanan budidaya, khususnya budidaya ikan air tawar, maka Kementerian Kelautan dan Perikanan (KKP) menggulirkan program Gerakan Pakan Ikan Mandiri (GERPARI). Program GERPARI merupakan salah satu bentuk pemberdayaan masyarakat dalam usaha budidaya ikan., sehingga pembudidaya menjadi lebih mandiri dan mempunyai tingkat pendapatan yang lebih baik yang akhirnya secara langsung akan meningkatkan kesejahteraan masyarakat serta ketahanan pangan dan gizi (CNN Indonesia, 2015). Tujuan penyaluran bantuan GERPARI adalah untuk meningkatkan pembuatan dan pemanfaatan pakan ikan secara mandiri dari berbagai jenis bahan baku lokal, mengurangi biaya produksi usaha budidayadan terbangunnya jejaring pakan mandiri nasional, pada akhirnya terujudnya kesejahteraan masyarakat serta ketahanan paangan dan gizi (Kementrian Kelautan dan Perikanan, 2015).

Pembangunan kesejahteraan sosial ekonomi masyarakat adalah serangkaian aktivitas yang terencana dan melembaga yang ditujukan untuk meningkatkan standar dan kualitas kehidupan manusia. Sebagai sebuah proses untuk meningkatkan kondisi sejahtera, istilah kesejahteraan masyarakat mengacu pada sektor atau bidang yang termasuk dalam wialayah pembangunan sosial yang secara konseptual mencakup segenap proses dan aktivitas mensejahterakan warga negara dan bukanlah semata-mata menunjuk pada kemakmuran yang bersifat fisik atau ekonomi saja (Suharto, 2006). Indikator kesejahteraan menurut Badan Pusat Statistik (BPS) 2015:

1) Kependudukan

2) Kesehatan dan Gizi

3) Pendidikan

4) Ketenagakerjaan (Pendapatan

5) Taraf dan pola konsumsi keluarga

6) Perumahan dan lingkungan

7) Kemiskinan

8) Indikator sosial Iain

\section{Kerangka Pemikiran dan Hipotesis}

Berdasarkan kajian teori di atas, adapun yang menjadi kerangka pemikiran dalam kegiatan penelitian ini adalah perubahan kondisi kesejahteraan petani peserta Program GERPARI melalui pemberian modal dan mesin pakan ikan dalam berusaha budidaya ikan. Petani peserta program sebagai produsen atau pengelola dituntut untuk dapat menjalankan usahanya dengan memanfaatkan bantuan dari Progam GERPARI dengan sebaik mungkin, sehingga dapat memperoleh manfaat dan meningkatkan hasil usahanya atau keuntungan serta kesejahteraan petani budidaya ikan lebih baik dari sebelum ikut program sehingga tujuan dari program tersebut tercapai. Tahapan yang akan dilaksanakan dalam penelitian ini adalah 
mendeskripsikan kondisi kesejahteraan petani petani peserta Program GERPARI dalam berusaha budidaya ikan dan menganalisis adakah terdapat perbedaan kondisi kesejahteraan petani dari sebelum dengan setelah adanya program GERPARI, sebagaimana disampaikan pada Gambar 1.

Program Gerakan Pakan Ikan Mandiri (GERPARI)

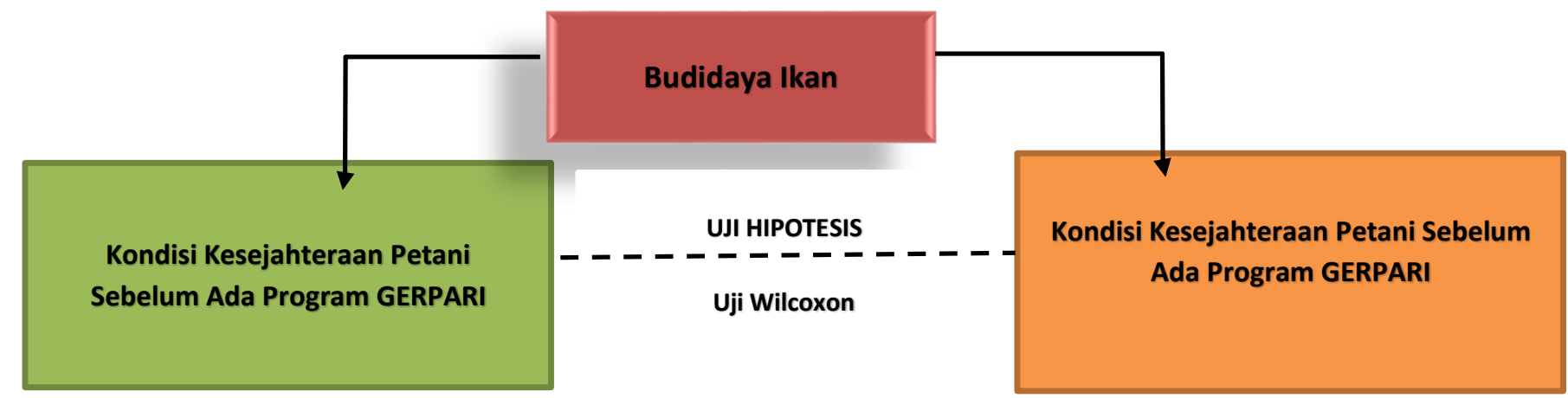

Gambar 1. Kerangka Pikir Penelitian

Dari penjelasan dan permasalahan yang sudah dijelaskan diatas, maka ditetapkan bahwa $X_{A}$ adalah kondisi kesejahteraan petani ikan sebelum adanya program GERPARI dan $\mathrm{X}_{\mathrm{B}}$ adalah kondisi kesejahteraan petani ikan setelah adanya program GERPARI. Hipotesis yang diajukan dalam penelitian ini adalah diduga terdapat perubahan kondisi kesejahteraan petani ikan sebelum dan setelah adanya program GERPARI di Kelurahan Jembatan Emas Kecamatan Pemayung Kabupaten Batang Hari, dengan bentuk hipotesis statistik: $\mathrm{H}_{0}: \mathrm{P}\left(\mathrm{X}_{\mathrm{A}}>\mathrm{X}_{\mathrm{B}}\right)=\mathrm{P}\left(\mathrm{X}_{\mathrm{A}}<\mathrm{X}_{\mathrm{B}}\right)=0,5$ dan $\mathrm{H}_{1}: \mathrm{P}\left(\mathrm{X}_{\mathrm{A}}>\right.$ $\left.X_{B}\right) \neq P\left(X_{A}<X_{B}\right) a \neq 0,5$.

\section{METODE PENELITIAN Tempat dan Waktu}

Penelitian ini dilaksanakan $\mathrm{Di}$ Kelurahan Jembatan Emas Kecamatan Pemayung Kabupaten Batang Hari. Pemilihan lokasi penelitian dipilih secara sengaja (purposive), karena di Kelurahan Jembatan Emas terdapat petani budidaya ikan yang dinyatakan sebagai peserta Program GERPARI yang jumlahnya terbanyak, pelaksanaan program telah terlaksana secara berkelanjutan dan kegiatannya berkembang secara positif dibandingkan dengan lokasi lain (Laporan DKP Provinsi Jambi, 2017) serta sampai dengan sekarang kegiatan usaha semakin berkembang. Pengumpulan data penelitian di laksanakan mulai dari bulan Mei sampai dengan Juni 2019.

\section{Tehnik Pengambilan Sampel}

Populasi dari penelitian ini adalah petani budidaya ikan yang dinyatakan sebagai peserta Program GERPARI di Kelurahan Jembatan Emas Kecamatan Pemayung Kabupaten Batang Hari. Pengambilan sampel dilakukan dengan metode sensus, artinya bahwa semua petani budidaya ikan peserta Program GERPARI di Keluarahan Jembatan Emas dijadikan responden dalam penelitian, yaitu sebanyak 25 orang.

\section{Pengumpulan Data}

Metode yang digunakan dalam penelitian adalah metode survey. Jenis data yang dikumpulkan berdasarkan waktu adalah jenis data cross section, berdasarkan skala ukur adalah jenis data ordinal, dan berdasarkan sumber adalah dari data primer yang diperoleh dari petani ikan peserta Program GERPARI melalui wawancara secara langsung dengan menggunakan kuesioner dan data sekunder diperoleh dari bahan bacaan serta dari instansi terkait yang berhubungan dengan penelitian ini.

\section{Metode Analisis Data}

Data yang terkumpul ditabulasi dan diolah dalam bentuk jumlah dan persentasi, kemudian data dianalisis secara deskriptif kualitatif-kuantitatif untuk mengetahui kondisi kesejahteraan petani peserta program. Pengukuran tingkat kesejahteraan petani menggunakan indikator kesejahteraan menurut Badan Pusat Statistik (BPS) 2015, yaitu berdasarkan indikator pendapatan, kesehatan dan gizi, pendidikan, taraf dan pola konsumsi keluarga serta perumahan dan lingkungan.

Pengujian hipotesis dilakukan untuk membuktikan apakah hipotesis dalam penelitian ini diterima atau ditolak melalui analisis Uji Wilcoxon dengan menggunakan Program PSPSS. Analisis ini digunakan untuk melihat dampak Program GERPARI dalam berusaha budidaya ikan terhadap kondisi kesejahteraan petani di Kelurahan Jembatan Emas Kecamatan Pemayung Kabupaten Batang Hari, dengan formulasi rumus (Sugiyono, 2004) sebagai berikut:

$z=\frac{T-\frac{n(n+1)}{4}}{\sqrt{\frac{n(n+1)(2 n+1)}{24}}}$

Dimana : 
$\mathrm{T}=$ Nilai yang lebih kecil antara $\mathrm{T}^{+}$dan $\mathrm{T}^{-}$

$\mathrm{N} \quad=$ Jumlah sampel

Catatan: Jika terdapat selisih yang bernilai nol maka jumlah $\mathrm{n}$ atau sampel akan berkurang.

Kreteria uji adalah :

Jika $\mathrm{z}$ hit $\geq \mathrm{z}$ tabel dengan $\alpha=5 \%$; maka $\mathrm{H}_{0}$ ditolak dan $\mathrm{H}_{1}$ diterima, berarti terdapat dampak Program GERPARI terhadap kondisi kesejahteraan petani budidaya ikan di Kelurahan Jembatan Emas Kecamatan Pemayung Kabupaten Batang Hari.

Jika $\mathrm{z}$ hit $\leq \mathrm{z}$ tabel dengan $\alpha=5 \%$; maka $\mathrm{H}_{0}$ diterima dan $\mathrm{H}_{1}$ ditolak, berarti tidak terdapat dampak Program GERPARI terhadap kondisi kesejahteraan petani budidaya ikan di Kelurahan Jembatan Emas Kecamatan Pemayung Kabupaten Batang Hari.

\section{HASIL DAN PEMBAHASAN \\ Kondisi Kesejahteraan Petani Peserta Program GERPARI}

Kondisi tingkat kesejahteraan petani peserta Program GERPARI pada penelitian ini diukur berdasarkan indikator kesejahteraan masyarakat menurut Badan Pusat statistik (2015), yaitu berdasarkan indikator pendapatan, kesehatan, pendidikan, taraf dan pola konsumsi keluarga, serta perumahan dan lingkungan. Uraian hasil penelitian dan pembahasannya adalah sebagai berikut:

\section{Kondisi Kesejahteraan Berdasarkan Indikator Pendapatan}

Dalam penelitian ini, pendapatan yang diterima petani merupakan salah satu indikator untuk mengukur kondisi kesejahteraan petani budidaya ikan peserta Program GERPARI. Semakin besar pendapatan yang diperoleh petani budidaya ikan, maka semakin tinggi tingkat kesejahteraan keluarga petani tersebut. Indikator pendapatan diukur dari rata-rata pendapatan total keluarga petani perbulan dibagi dengan jumlah anggota keluarga dan rata-rata jam kerjanya petani dan anggota keluarganya selama seminggu. Untuk menentukan kategori kondisi tingkat kesejahteraan petani berdasarkan indikator pendapatan, maka jumlah pendapatan petani perkapita perbulan dibandingkan dengan UMR Kabupaten Batang Hari yang berlaku yaitu sebesar $\mathrm{Rp}$ 2.040.000 dan rata-rata jam kerja normal dalam seminggu yaitu sebesar 35 jam perminggu. Kondisi kesejahteraan rumah tangga petani budidaya ikan peserta Program GERPARI berdasarkan indikator pendapatan di Kelurahan Jembatan Emas Kecamatan Pemayung Kabupaten Batang Hari dapat dilihat pada Tabel 1.

Tabel 1. Kesejahteraan Petani Peserta Program GERPARI Berdasarkan Indikator Pendapatan

\begin{tabular}{clcccc}
\hline \multirow{2}{*}{ No } & \multicolumn{2}{c}{ Kategori } & \multicolumn{2}{c}{ Sebelum Ada Program } & \multicolumn{2}{c}{ Setelah Ada Program } \\
& Kesejahteraan & Jumlah (Orang) & Persentase (\%) & Jumlah (Orang) & Persentase (\%) \\
\hline 1 & Kesjahteraan Rendah & 17 & 68 & 0 & 8 \\
2 & Kesejahteraan Sedang & 8 & 32 & 18 & 72 \\
3 & Kesejahteraan Tinggi & 0 & 8 & 7 & 28 \\
& Jumlah & 25 & 100 & 25 & 100 \\
\hline
\end{tabular}

Sumber: Data Primer Diolah, 2019

Dari Tabel 1 di atas terlihat bahwa sebelum ikut atau adanya Program GERPARI, 68\% petani peserta program kondisi kesejahteraannya termasuk kategori rendah dan 32\% termasuk pada kategori sedang. Kesejahteraan petani dikaregorikan rendah karena pendapatan yang diperolah petani perkapita perbulan masih di bawah angka UMR Kabupaten Batang Hari (< Rp 2.040.000) dan jam kerjanya dalam seminggu tidak normal (<35 Jam). Setelah menjadi peserta Program GERPARI, kondisi kesejahteraan petani budidaya ikan di Kelurahan Jembatan Emas mengalami peningkatan yaitu $72 \%$ petani berada pada kategori sedang dan $28 \%$ petani berada pada kategori tinggi. Petani dikatakan kondisi kesejahteraannya berada pada kategori sedang dan tinggi karena pendapatan petani budidaya ikan perkapita perbulan sudah setara dan ada yang lebih besar dari nilai UMR Kabupaten Batang Hari $(\geq \mathrm{Rp}$ 2.040.000)

Kesejahteraan subjektif juga mempunyai hubungan dengan pendapatan keluarga. Adanya pemberian bantuan modal dalam berusaha budidaya ikan melalui Program GERPARI berdampak terhadap kesejakteraan petani. Modal yang diberikan dapat digunakan untuk memenuhi kebutuhan dalam berusaha budidaya ikan. Input meningkat output juga akan meningkat, sehingga pendapatan petani dapat meningkat. Bertambahnya pendapatan petani maka tingkat kesejahteraan petani juga akan meningkat. Alabi et al. 2006 juga menjelaskan bahwa pendapatan merupakan sumber daya utama keluarga yang digunakan untuk membeli berbagai kebutuhan keluarga, semakin besar pendapatan keluarga maka keluarga akan semakin dapat memenuhi kebutuhan hidupnya sehingga kesejahteraan keluarga dapat terujud.

\section{Kondisi Kesejahteraan Berdasarkan Indikator Kesehatan}

Kesehatan keluarga merupakan salah satu indikator penting dalam mengukur tingkat kesejahteraan. Indikator kesehatan diukur dari kemampuan petani mengeluarkan biaya untuk berobat dan kartu jaminan kesehatan yang mereka miliki untuk mendapatkan pelayanan yang baik dalam berobat. Semakin tinggi kemampuan petani mengeluarkan biaya untuk berobat dan tersedianya kartu jaminan kesehatan serta mendapatkan pelayanan yang baik maka dapat dikatakan semakin sejahtera petani tersebut. Kondisi kesejahteraan rumah tangga petani budidaya ikan peserta Program GERPARI berdasarkan indikator kesehatan di Kelurahan Jembatan Emas Kecamatan Pemayung Kabupaten Batang Hari dapat dilihat pada Tabel 2. 
Asmaida dan Rogayah, Dampak Program Gerakan Pakan Ikan Mandiri (GERPARI) terhadap Kesejahteraan Petani lkan di Kelurahan Jembatan Emas Kecamatan Pemayung Kabupaten Batang Hari

Tabel 2. Kesejahteraan Petani Peserta Prgram GERPARI Berdasarkan Indikator Kesehatan

\begin{tabular}{clcccc}
\hline \multirow{2}{*}{ No } & \multirow{2}{*}{ Kategori } & \multicolumn{2}{c}{ Sebelum ada program } & \multicolumn{2}{c}{ Setelah ada program } \\
& & Jumlah (Orang) & Persentase (\%) & Jumlah (Orang) & Persentase (\%) \\
\hline 1 & Kesjahteraan Rendah & 15 & 60 & 0 & 0 \\
2 & Kesejahteraan Sedang & 9 & 36 & 14 & 56 \\
3 & Kesejahteraan Tinggi & 1 & 4 & 11 & 44 \\
& Jumlah & 25 & 100 & 25 & 100 \\
\hline
\end{tabular}

Sumber: Data Primer Diolah, 2019

Dari Tabel 2 di atas terlihat bahwa sebelum ikut atau adanya Program GERPARI, $60 \%$ petani peserta program kondisi kesejahteraannya adalah termasuk kategori rendah, $36 \%$ petani berada pada kategori sedang dan $4 \%$ petani berada pada kategori tinggi. Kondisi kesejahteraan petani dikaregorikan rendah karena kemampuan petani mengeluargan biaya berobat untuk keluarganya hanya baru bisa mengeluarkan biaya untuk membayar jasa bidan/perawat, petani merasakan pelayanan yang didapat belum memuaskan dan petani belum ada memiliki kartu jaminan kesehatan. Setelah menjadi peserta program GERPARI, kondisi kesejahteraan petani di Kelurahan Jembatan Emas mengalami peningkatan yaitu $56 \%$ petani berada pada kategori sedang dan $44 \%$ petani berada pada kategori tinggi. Kondisi kesejahteraan petani dikatakan termasuk dalam kategori sedang dan tinggi karena petani sudah mampu mengeluargan biaya berobat untuk keluarganya dengan menggunakan jasa dokter umum atau dokter sepesialis, petani sudah merasa mendapatkan pelayanan yang baik dan sebagian besar petani sudah memiliki kartu jaminan kesehatan.

Tingkat kesejahteraan mempunyai hubungan dengan indikator kesehatan. Kesehatan seseorang akan meningkat antara lain jika pada saat sakit mereka mempunyai kemampuan untuk mengeluarkan biaya berobat dan memiki kartu jaminan kesehatan untuk mendapatkan pelayanan yang baik. Rambe (2004) dalam Puspitasari, N (2013) yang menyatakan bahwa pengeluaran total keluarga berpengaruh positif dan signifikan terhadap pendapatan total keluarga. Kesejahteraan keluarga secara objektif berhubungan signifikan dan positif dengan aspek ekonomi. Artinya jika petani sudah mempunyai kemampuan untuk memenuhi pengeluaran keluarga khususnya dalam berobat bearti salah satu indikator peningkatan kesejahteraan telah terpenuhi.

\section{Kondisi Kesejahteraan Berdasarkan Indikator Pendidikan}

Pendidikan juga merupakan salah satu indikator yang digunakan untuk mengukur kondisi kesejahteraan petani budiday ikan. Tinggi tingkat pendidikan suatu anggota keluarga, maka keluarga tersebut dapat dikatakan sebagai keluarga yang sejahtera. BPS 2015, menyatakan pendidikan merupakan salah satu modal yang sangat penting dalam kehidupan bermasyarakat. Melalui pendidikan seseorang dapat memperoleh bermacam informasi dan ilmu pengetahuan yang sangat berguna untuk dirinya dalam menjalani kehidupan. Dengan pendidkan yang dimiliki seseorang diharapkan akan lebih mempunyai kesejahteraan yang lebih baik. Sementara tingkat pendidikan anggota keluarga dipengaruhi oleh kemampuan dan keinginan kepala keluarga untuk mengeluarkan biaya pendidikan anaknya. Kondisi kesejahteraan rumah tangga petani budidaya ikan peserta Program GERPARI berdasarkan indikator pendidikan di Kelurahan Jembatan Emas Kecamatan Pemayung Kabupaten Batang Hari dapat dilihat pada Tabel 3 .

Tabel 3. Kesejahteraan Petani Peserta Prgram GERPARI Berdasarkan Indikator Pendidikan

\begin{tabular}{clcccc}
\hline \multirow{2}{*}{ No } & \multicolumn{1}{c}{ Kategori } & \multicolumn{2}{c}{ Sebelum ada program } & \multicolumn{2}{c}{ Setelah ada program } \\
& & Jumlah (Orang) & Persentase (\%) & Jumlah (Orang) & Persentase (\%) \\
\hline 1 & Kesjahteraan Rendah & 15 & 60 & 0 & 0 \\
2 & Kesejahteraan Sedang & 10 & 40 & 12 & 48 \\
3 & Kesejahteraan Tingii & 0 & 0 & 13 & 52 \\
& Jumlah & 25 & 100 & 25 & 100 \\
\hline
\end{tabular}

Sumber : Data Primer Diolah, 2019

Dari Tabel 3 di atas terlihat bahwa sebelum ikut atau adanya Program GERPARI, $60 \%$ petani pesetrta program kondisi kesejahteraannya adalah termasuk kategori rendah dan $40 \%$ petani termasuk dalam kategori sedang. Kondisi kesejahteraan petani dikaregorikan rendah karena kemampuan petani mengeluarkan biaya untuk pendidikan anaknya hanya mampu sampai tingkat SLTP. Setelah menjadi peserta program GERPARI, kondisi kesejahteraan petani di Kelurahan Jembatan Emas mengalami peningkatan sebanyak $48 \%$ petani sudah berada pada kategori sedang dan $52 \%$ petani berada pada kategori tinggi. Artinya keberadaan program GERPARI mempunyai dampak terhadap tingkat kesejahteraan petani, petani sudah mampu membiayai pendidikan anaknya sampai ke jenjang perguruan tinggi.

\section{Kondisi Kesejahteraan Berdasarkan Indikator Taraf dan Pola Komsumsi}

Taraf dan pola konsumsi keluarga juga merupakan salah satu indikator dalam mengukur apakah suatu keluarga dikatakan keluarga sejahtera atau tidak. Semakin baik pola konsumsi dan simbangnya nilai gizi yang dikonsumsi suatu keluarga, maka keluarga tersebut akan semakin sejahtera. Gizi seimbang itu terdiri dari karbohidrat, protein, sayur, buah dan susu sesuai kebutuhan. Dalam hal ini untuk bisa mengkonsumsi gizi yang seimbang tentu juga diiringi 
dengan pengeluaran yang besar, kenyataannya keluarga para petani dipedesaan sangat sedikit sekali yang bisa mengkonsumsi makanan dengan gizi seimbang bahkan tidak bisa untuk setiap hari. Kondisi kesejahteraan petani peserta Program GERPARI berdasarkan indikator taraf dan pola konsumsi di Kelurahan Jembatan Emas Kecamatan Pemayung Kabupaten Batang Hari dapat dilihat pada Tabel 4.

Tabel 4. Kesejahteraan Petani Peserta Prgram GERPARI Berdasarkan Indikator Taraf dan Pola Konsumsi

\begin{tabular}{clcccc}
\hline \multirow{2}{*}{ No } & \multirow{2}{*}{ Kategori } & \multicolumn{2}{c}{ Sebelum ada program } & \multicolumn{2}{c}{ Setelah ada program } \\
& & Jumlah (Orang) & Persentase (\%) & Jumlah (Orang) & Persentase (\%) \\
\hline 1 & Kesjahteraan Rendah & 14 & 56 & 0 & 0 \\
2 & Kesejahteraan Sedang & 10 & 40 & 16 & 64 \\
3 & Kesejahteraan Tinggi & 1 & 4 & 9 & 36 \\
& Jumlah & 25 & 100 & 100 & \\
\hline
\end{tabular}

Sumber : Data Primer Diolah, 2019

Dari Tabel 4 di atas terlihat bahwa sebelum ikut atau adanya Program GERPARI, 56\% petani peserta program kondisi kesejahteraannya adalah termasuk kategori rendah, $40 \%$ petani termasuk dalam kategori sedang dan $4 \%$ petani berada pada kategori tinggi. Kondisi kesejahteraan petani dikaregorikan rendah karena petani belum mampu mencukupi biaya pengeluaran untuk menyediakan makanan keluarganya dengan menu kandungan gizi yang dikonsumsi belum mencukupi serta pola makan yang belum teratur. Petani berserta keluarganya hanya rata-rata mengkonsumsi karbohidrat ditambah protein atau sayuran. Setelah menjadi peserta Program GERPARI, kondisi kesejahteraan petani budidaya ikan di Kelurahan Jembatan Emas mengalami peningkatan yaitu 64\% petani berada pada kategori sedang dan 36\% petani berada pada kategori tinggi. Artinya keberadaan program GERPARI mempunyai dampak terhadap kondisi kesejahteraan petani diukur dari indikator taraf dan pola konsumsi, dimana petani sudah mampu mencukupi biaya pengeluaran untuk makanan anggota keluarganya yaitu menyediakan menu karbohidrat, protein, sayur, buah, dan susu serta kandungan gizi yang dikonsumsi sudah seimbang dan pola makan juga sudah mulai teratur.

\section{Kondisi Kesejahteraan Berdasarkan Indikator Perumahan Dan Lingkungan}

Tempat tinggal dan lingkungan termasuk faktor utama yang menjadi indikator tingkat kesejahteraan. Apabila suatu keluarga sudah mampu memiliki rumah sendiri dengan kondisi yang nyaman dan bersih serta fasilitas yang cukup maka bisa dikatakan bahwa keluarga tersebut masuk dalam kategori keluarga yang sejahtera. Sebagian besar penduduk yang bermukim di wilayah pedesaan sudah memiliki tempat tinggal sendiri dengan kondisi fasilitas dan status kepemilikan rumah tempat tinggal yang berbeda-beda. Status rumah tempat tinggal ada rumah warisan dan ada rumah hasil bangun sendiri. Kondisi kesejahteraan petani peserta Program GERPARI berdasarkan indikator perumahan dan lingkungan di Kelurahan Jembatan Emas Kecamatan Pemayung Kabupaten Batang Hari dapat dilihat pada Tabel 5.

Tabel 5. Kesejahteraan Petani Peserta Prgram GERPARI Berdasarkan Indikator Perumahan dan Lingkungan

\begin{tabular}{clcccc}
\hline \multirow{2}{*}{ No } & \multirow{2}{*}{ Kategori } & \multicolumn{2}{c}{ Sebelum ada program } & \multicolumn{2}{c}{ Setelah ada program } \\
& & Jumlah (Orang) & Persentase (\%) & Jumlah (Orang) & Persentase (\%) \\
\hline 1 & Kesjahteraan Rendah & 14 & 56 & 1 & 4 \\
2 & Kesejahteraan Sedang & 10 & 40 & 19 & 76 \\
3 & Kesejahteraan Tinggi & 1 & 4 & 5 & 20 \\
& Jumlah & 25 & 100 & 25 & 100 \\
\hline
\end{tabular}

Sumber : Data Primer Diolah, 2019

Dari Tabel 5 di atas terlihat bahwa sebelum ikut atau adanya program GERPARI, 56\% petani kondisi kesejahteraannya adalah termasuk kategori rendah, $40 \%$ petani termasuk kategori sedang dan $4 \%$ berada pada kategori tinggi. Kondisi kesejahteraan petani dikaregorikan rendah karena petani masih ada yang tinggal menompang dan status rumah yang ditempati adalah rumah dari warisan, fasilitas rumah masih dalam kondisi yang sederhana dan belum memadai seperti dalam memasak petani masih banyak menggunakan kayu sebagai bahan bakar dan toilet masih diluar rumah. Setelah menjadi peserta Program GERPARI, kondisi kesejahteraan petani di Kelurahan Jembatan Mas mengalami peningkatan yaitu $76 \%$ petani sudah berada pada kategori sedang dan $20 \%$ petani sudah berada pada kategori tinggi. Artinya keberadaan program GERPARI mempunyai dampak terhadap tingkat kesejahteraan petani diukur dari indikator kondisi perumahan dan lingkungan, dimana petani sudah mampu membangun rumah sendiri, memiliki fasilitas perumahan dan lingkungan yang memadai yaitu sudah tersedia air bersih, toilet dalam rumah dan menggunakan gas untuk bahan bakar memasak.

\section{Dampak Program GERPARI Terhadap Perubahan Kesejahteraan Petani}

Berdasarkan pembahasan hasil penelitian di atas, dari lima indikator yang diukur yaitu pendapatan, kesehatan, pendidikan, taraf dan pola konsumsi, serta perumahan dan lingkungan, yang dijadikan sebagai tolak ukur untuk melihat kondisi kesejahteraan petani nudidaya ikan peserta program di Kelurahan Jembatan Emas Kecamatan Pemayung Kabupaten Batang Hari, dimana kondisi kesejahteraan petani setelah menjadi peserta program GERPARI terdapat 4 indikator yang mengalami perubahan yaitu pendapatan, kesehatan, 
Asmaida dan Rogayah, Dampak Program Gerakan Pakan Ikan Mandiri (GERPARI) terhadap Kesejahteraan Petani lkan di Kelurahan Jembatan Emas Kecamatan Pemayung Kabupaten Batang Hari

pendidikan, taraf dan pola konsumsi yang berdampak terhadap peningkatan kesejahteraan petani budidaya ikan. Kondisi kesejahteraan petani peserta program GERPARI dapat dilihat pada Tabel 6.

Tabel 6. Kesejahteraan Petani Peserta Prgram GERPARI

\begin{tabular}{clcccc}
\hline \multirow{2}{*}{ No } & \multirow{2}{*}{ Kategori } & \multicolumn{2}{c}{ Sebelum ada program } & \multicolumn{2}{c}{ Setelah ada program } \\
& & Jumlah (Orang) & Persentase (\%) & Jumlah (Orang) & Persentase (\%) \\
\hline 1 & Kesjahteraan Rendah & 22 & 88 & 0 & 0 \\
2 & Kesejahteraan Sedang & 3 & 18 & 11 & 44 \\
3 & Kesejahteraan Tinggi & 0 & 0 & 14 & 56 \\
& Jumlah & 25 & 100 & 25 & 100 \\
\hline
\end{tabular}

Sumber : Data Primer Diolah, 2019

Dari Tabel 6 di atas dapat dilihat bahwa sebelum ikut atau adanya program GERPARI dari jumlah total petani peserta program tersebut, sebanyak $88 \%$ petani kondisi kesejahteraannya masih berada dalam kategori rendah dan $18 \%$ sudah berada dalam kategori sedang. Setelah ikut sebagai peserta program, yang sebelumnya berada pada kategori rendah semuanya mengalami perubahan yang mana kondisi kesejahteraannya meningkat yaitu $44 \%$ petani berada pada kategori sedang dan $56 \%$ petani berada pada kategori tinggi. Secara keseluruhan dapat disimpulkan bahwa kondisi kesejahteraan petani budidaya ikan peserta program GERPARI di Kelurahan Jembatan Emas Kecamatan Pemayung Kabupaten Batang Hari mengalami perubahan dari kategori rendah sebelum ikut atau adanya program GERPARI dan meningkat menjadi kategori sedang setelah ikut sebagai peserta Program GERPARI.

Berdasakan pengujian secara statistik dengan menggunakan uji Wilcoxon terhadap perubahan kesejahteraan petani budidaya ikan di Kelurahan Jembatan Mas Kecamatan Pemayung Kabupaten Batang Hari, diperoleh output SPSS, yaitu dengan hasil : (1) Negatif ranks atau selisih (negative) antara nilai skor kondisi kesejahteraan petani ikan sebelum dan setelah adanya Program GERPARI adalah 0 , baik pada nilai N, Mean Rank dan Sum of Ranks. Nilai ini menunjukkan tidak adanya penurunan nilai dari sebelum ada program ke setelah ada program. (2) Positif ranks atau selisih (positif) antara nilai skor kondisi kesejahteraan petani ikan sebelum dan setelah adanya Program GERPARI adalah terdapat 25 data yang positif yang artinya sebanyak 25 petani ikan mengalami peningkatan kondisi kesejahteraan dari sebelum dan setelah adanya program. Mean rank atau rata-rata nilai skor peningkatan tersebut adalah sebesar 13, sedangkan jumlah ranking positif atau sum of ranks adalah sebesar 325,00. (3) Tidak ada kesamaan nilai skor kondisi kesejahteraan petani sebelum dan setelah adanya program GERPARI, terlihat nilai ties adalah 0 , sehingga dapat dikatakan bahwa tidak ada nilai yang sama antara kondisi kesejahteraan petani ikan sebelum dan setelah ada program GERPARI. 4) Nilai Asymp. Sig. (2-tailed) bernilai 0,000, angka tersebut lebih kecil dari nilai alfa sebesar 0,05. Maka keputusannya adalah terima $H_{1}$, artinya terdapat perubahan kondisi kesejahteraan rumah tangga petani budidaya ikan di Kelurahan Jembatan Mas Kecamatan Pemayung Kabupaten Batang Hari sebelum dan selelah adanya program GERPARI atau dapat disimpulkan Progam GERPARI mempunyai dampak terhadap kondisi kesejahteraan rumah tangga petani budidaya ikan di Kelurahan Jembatan Mas Kecamatan Pemayung Kabupaten Batang Hari diukur dari indikator pendapatan, kesehatan, pendidikan, taraf dan pola konsumsi, serta perumahan dan lingkungan.

\section{SIMPULAN}

1. Dari 5 indikator kesejahteraan yang diukur, sebelum ikut atau adanya Program GERPARI rata-rata kondisi kesejahteraan petani berdasarkan indikator pendapatan, kesehatan, pendidikan, taraf dan pola konsumsi, serta perumahan dan lingkungan termasuk dalam kategori rendah. Selelah ikut sebagai peserta Program GERPARI, dari nilai indikator pedapatan, taraf dan pola konsumsi keluarga, serta perumahan dan lingkungan kondisi kesejahteraan petani budidaya ikan peserta program berada pada kategori sedang, sedangkan dari nilai indikator kesehatan dan pendidikan berada pada kategori tinggi. Secara keseluruhan sebelum ikut atau adanya program, sebanyak $88 \%$ petani budidaya ikan peserta program kondisi kesejahteraannya berada pada kategori rendah dan $12 \%$ berada pada kategori sedang. Setelah ikut sebagai peserta Program GERPARI, kondisi kesejahteraan petani budidaya ikan mengalami peningkatan yaitu sebanyak $44 \%$ berada pada kategori sedang dan $56 \%$ berada pada kategori tinggi. Artinya kondisi kesejahteraan petani budidayai ikan peserta program meningkat karena pendapatan petani perkapita perbulan rata-rata sudah setara dengan nilai UMR Kabupaten Batang Hari dengan rata-rata jam kerja 35 jam per minggu. Petani sudah mempunyai kemampuan untuk mengeluarkan biaya berobat dan memiliki kartu jaminan kesehatan untuk mendapatkan pelayanan yang baik untuk anggota keluarga. Petani sudah mendapatkan kemudahan dan mempunyai kemampuan menyekolahkan anak ketingkat perguruan tinggi. Petani mampu mencukupi biaya pengeluaran untuk makanan anggota rumah tangga dan konsumsi protein yang seimbang dengan pola yang teratur. Petani memiliki fasilitas perumahan dan lingkungan yang memadai (rumah milik sendiri, air bersih, tersedia toilet dan menggunakan gas untuk bahan bakar memasak).

2. Adanya bantuan program GERPARI yang diterima petani budidaya ikan di Kelurahan Jembatan Mas Kecamatan Pemayung Kabupaten Batang Hari memberikan perubahan yang signifikan terhadap peningkatan kondisi kesejahteraan petani budidaya ikan diukur dari indikator pendapatan, kesehatan, 
pendidikan, taraf dan pola konsumsi, serta perumahan dan lingkungan.

\section{DAFTAR PUSTAKA}

AG, Subarsono. 2010. Analisis Kebijakan Publik Konsep Teori dan Aplikasi. Pustaka Pelajar. Yogyakarta.

Alabi, D. L., Ogbimi, G. E., \& Soyebo, K. O. 2006. Factor Enhancing Efektive Financial Management of Rural Women in Osun State. Research Journal of Sosial Sciences. Obafemy Awolowo University, Ile-Ife, Nigeria.

Andi Angger Sutawijaya, Siti Rochaeni, Achmad Tjachja N. 2013. Analisis Tingkat Kesejahteraan Rumah Tangga Petani Ikan Hias Air Tawar Di Kelurahan Cipedak Kecamatan Jagakarta Kota Madya Jakarta Selatan. Jurnal Agribisnis, Vol.7, No.1: 5779

Asmaida. 2018. Manfaat Ekonomi Manfaat Ekonomi Yang Diterima Petani Peserta Program Gerakan Pakan Ikan Mandiri (GERPARI) Dalam Usaha Budidaya Ikan (Studi Kasus Di Desa Jembatan Mas Kecamatan Pemayung Kabupaten Batanghari) Fakultas Pertanian Universitas Batanghari Jambi. Jurnal IImiah Media Agribisnis Vol. 3 No 2: 48-60.

Badan Pusat Statistik. 2015. Indikator Kesejahteraan Masyarakat. BPS-Statistic Indonesia.

CNN Indonesia. 2015. Pakan Ikan di Dominasi Impor, http://www.cnnindonesia.com/ekonomi/201502201 43946-9233265/pakan-ikan didominasi-impormenteri-susi-luncurkan-gerpari./november 2017

Dinas Kelautan dan Perikanan. 2017. Laporan Kinerja Dinas Kelautan dan Perikanan Provinsi Jambi.

Direktorat Jenderal Perikanan Budidaya. 2017. Petunjuk Tekhnis Penyaluran Bantuan Gerakan Pakan Ikan Mandiri. Kementerian Kelautan dan Perikanan.

Hikmat, Harry. 2001. Strategi Pemberdayaan Masyarakat. Humaniora Utama Press Bandung.

Ihsan Efendi. 2004. Pengantar Akuakultur. Penebar Swadaya. Jakarta.

Kementerian Kelautan dan Perikanan. 2015. Laporan Kinerja Kementerian Kelautan dan Perikanan "Wujudkan Kemandirian Melalui Pakan Ikan Mandiri".

Manning. C and J. Suriya. 1996. Survey of Recent Development. Bulletin of Economic Studies. 28 (1). Indonesian Project. The Australian National University.

Novi Puspitasari et al. 2013. Peran Gender, Kontribusi Ekonimi Perempuan, dan Kesejahteraan Keluarga Petani Hortikultura. Jurnal IImu Keluarga dan Konsumen. Vol 6. No 1, p : 10-19.

Peraturan Presiden Republik Indonesia. 2015. Rencana Pembangunan Jangka Menengah Nasional Tahun 2015-2019.

Silalahi, U. 2010. Metode Penelitian Sosial. PT. Refika Aditama. Bandung.

Singarimbun. M dan S. Effendi. 1982. Metode Penelitian Survei. LP3ES. Jakarta.

Sugiono. 2013. Metode Penelitian Kuantitatif, Kualitatif dan R\&D. Alfabeta. Bandung.

Sunarso dan Crhistianto. 2000. Manajemen Pakan. Jakarta
Sunarno, M.T.D. 2012. Revitalisasi Pabrik Pakan Ikan Skala Mini Untuk Mendukung Bisnis Budidaya Ikan Lele di Kabupaten Gunung kidul, Provinsi Daerah Istimewa Yogyakarta, dalam Prosisding Seminar Nasional Riset dan kebijakan Sosial Ekonomi Kelautan dan Perikanan : p 19-34. Balai Besar Penelitian Sosial Ekonomi Kelautan dan Perikanan. 